\title{
THE MONREALE CAPITALS AND THE MILITARY EQUIPMENT OF LATER NORMAN SICILY
}

BY

DAVID NICOLLE

THE carved capitals of the Monreale Cathedral cloister near Palermo in Sicily are widely recognised as superb examples of south European Romanesque art. They have been discussed in relation to Romanesque carvings throughout Italy and southern France, and have been used to demonstrate the varying degrees of Islamic influence apparent in Sicilian and southern Italian sculpture. Their dating is reasonably certain: from 1174 to $1182 \mathrm{AD}$ according to Jacquiot and King, ${ }^{1}$ and from 1176 to 1189 AD according to G. H. Crichton. ${ }^{2}$ The Monreale capitals are thus the last in a series of three important Italo-Norman collections of carvings to show military scenes. The others are those above the north door of the church of San Nicola in Bari which may date from 1099 to 1106 AD, and the portal above the north door of the church of La Martorana in Palermo from around 1140 to $1143 \mathrm{AD}$.

Art historians have identified Islamic elements in the San Nicola north door, ${ }^{3}$ more specifically Fā imid Egyptian elements in the sculpted lintels of La Martorana, ${ }^{4}$ and predominantly French ${ }^{5}$ or predominantly Campanian ${ }^{6}$ influences in the Monreale cloister. Others have sought to define the precise channels through which specifically Andalusian or specifically Fātimid influences reached Sicily. No one, however, appears to have looked at the wide range of arms and armour portrayed on these Monreale sculptures. Here one can find weaponry that clearly includes western European, Byzantine and Islamic elements and which may tell us much, not only about those who carved these capitals but also about the troops of the ruler who commissioned them.

${ }^{1}$ J. JACQuiot \& E. KIng, in Larousse Encyclopedia of Byzantine and Medieval Art, edit. R. Huyghe, London, 1963, p. 298.

2 G. H. Crichton, Romanesque Sculture in Italy, London, 1954, p. 147.

${ }^{3}$ Crichton, op. cit., p. 155.

${ }^{4}$ Reference to G. Marcars in A. Ahmad, A History of Islamic Sicily, Edinburgh 1975, p. 99.

5ACQUIOT \& King, loc. cit.

${ }^{6}$ Crichton, op. cit., p. 147. 
The army of Norman Sicily was in many ways unique. Other countries employed both Muslim and Christian warriors, as allies of as auxiliaries, during the 11th and 12th centuries. Various Spanish kingdoms, the Duchy of Naples, certain Muslim dynasties in north Africa and Egypt, and of course Byzantium, all did so. But only in Norman Sicily did such varied contingents form the core of what was almost a professional force. According to most written sources two groups predominated. These

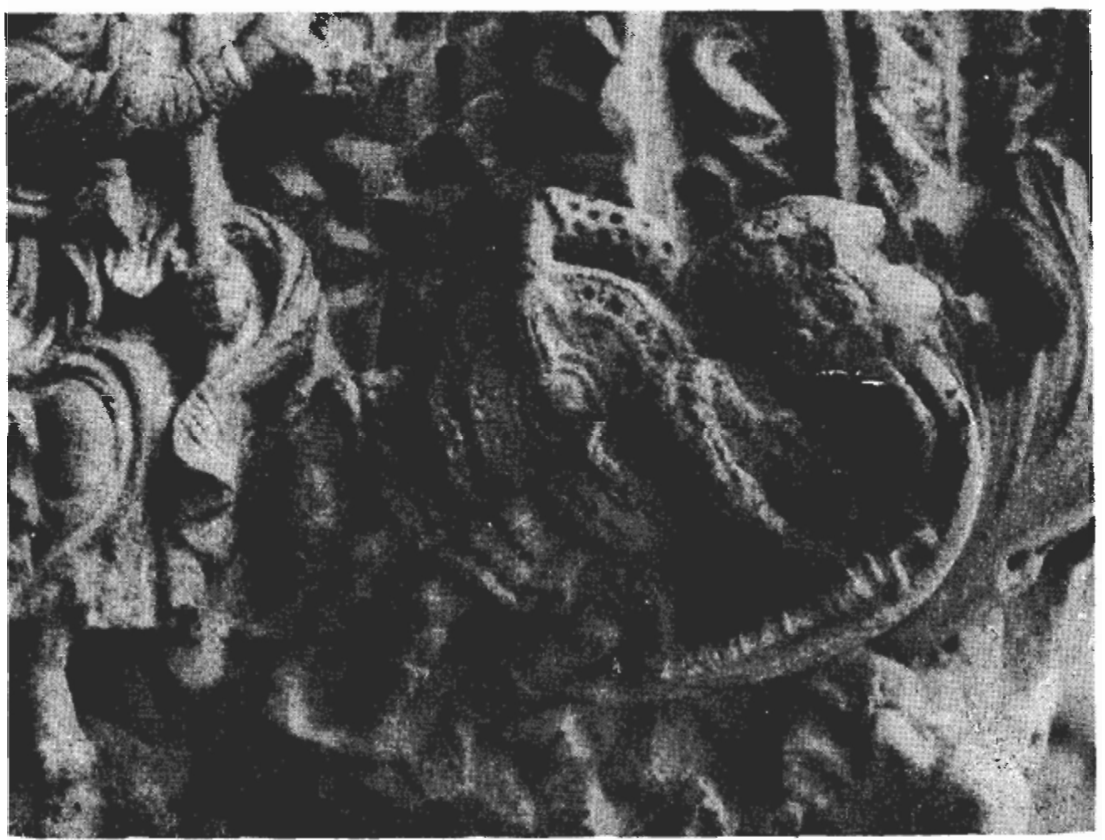

Fото I.-Capital, Cloister of Monreale Cathedral. Pre-Norman mail. Soldiers at Easter Sepulchre

were the Normans themselves and the previously dominant Arabicspeaking Muslims of western Sicily. Other groups may also have played their part, such as the Greek-speaking inhabitants of eastern Sicily and Italian-speaking immigrants from Lombardy and elsewhere. This last group may, rather confusingly, also have included members of a Lombard military aristocracy that had previously dominated southern Italy much as the Arabs had dominated Sicily. There might possibly have even 


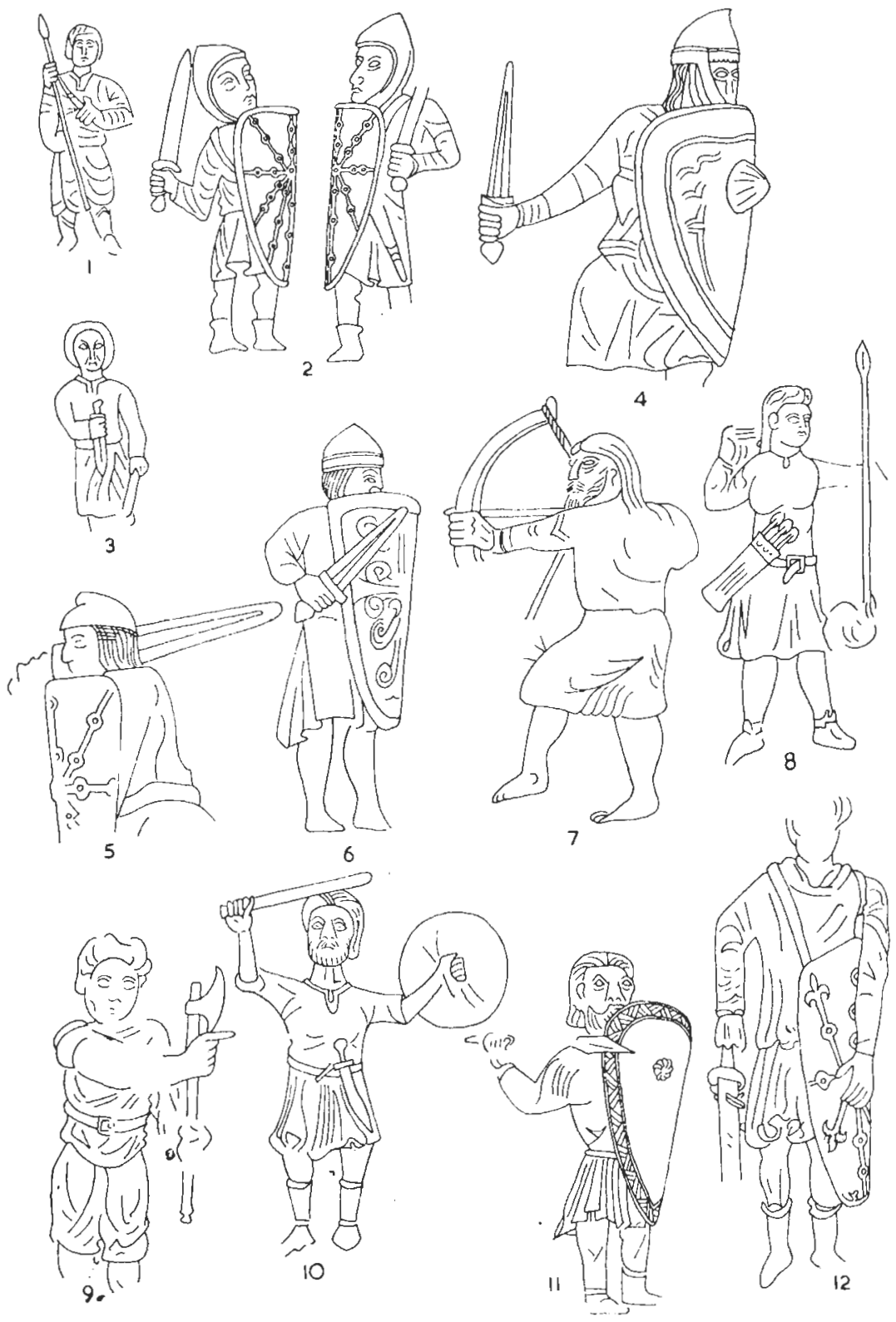

Figs. 1-12.-Capitals in the Cloister of Monreale Cathedral 1-12: «European» style infantry 
been a small influx of newly recruited Muslim mercenaries, Berbers, Arabs or negroes, from north Africa.

All such peoples, with their traditional weapons and defences, may

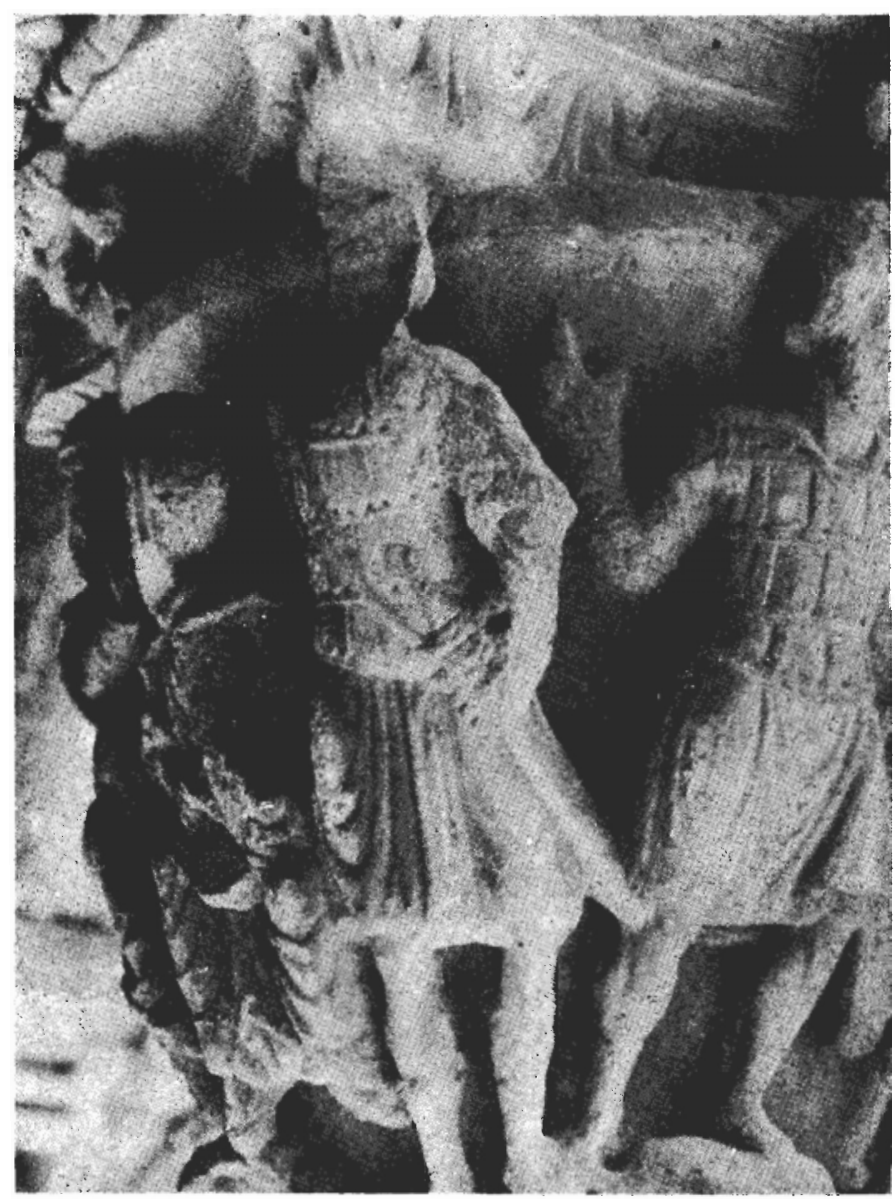

Foto II.-Capital, Cloister of Monreale Cathedral. Saracen-Byzantine style. Scale armour, loose turban

be illustrated in the Monreale cloister, though their precise identification is far from easy. The new Norman élite fought largely as heavy cavalry 
in a style comparable to that of the aristocracy of most of western Europe. The Sicilian Muslims fought for their new rulers most notably as skilled military engineers, for instance outside Capua in $1098 \mathrm{AD}$ and later by erecting the fortifications of Bari. Their continued importance in the Norman kingdom may be indicated by the continued use of Arabic military titles. Many of the previous Muslim iqtā's, a form of military land-holding, had been taken over and only slightly altered to form new Norman fiefs, but the old Muslim system of military organization, the jund, was preserved largely intact for many decades. In it Muslim soldiers fought both as infantry and as cavalry, though whether this jund was modified to include Christian warriors, Normans, Lombards, Italians or Greeks, is unclear. Other Muslims formed a personal guard for the sovereign, under the command of one of their own number. Another élite corps of archers protected certain aspects of government machinery. The importance of such Muslim troops had clearly declined by the end of the 12th century but it had far from disappeared. In fact these «Saracens» continued to participate in the Norman rulers' wars against Christian foes in Italy or the Balkans until the fall of the kingdom, though not against their co-religionists in north Africa.

There are five basic styles of military costume shown on the Monreale capitals. These are: full mail hauberk and helmet for both cavalry and infantry (Figs. 13, 14, 20 and Foto I); scale armour which is generally worn without a helmet by both cavalry and infantry (Figs. 18, 20-24 and Foto II); helmet but no apparent body armour, appearing only on infantry (Figs. 2, 4-6 and 17); and no apparent body armour or head protection, which again applied both to cavalry and infantry (Figs. 1, 3, $7-12,15,16,19,25$ and 26). Shields include the kite-shaped shield (Figs. 2, 4-6, 11-14, 25 and 26), more «kidney-shaped» shield (Fig. 17), relatively large round shield (Fig. 20) and the small hand-held round buckler (Figs. 10, 15, 19 and 38). Weaponry is more varied and includes the long lance (Figs. 14 and 37), the short spear or javelin (Figs. 8, 11, 16 and 36), the mace (Figs. 19 and 30-32), the axe (Figs. 9 and 33), the simple short-bow (Fig. 7) and an apparently composite recurve bow (Figs. 24, 34 and 35). Swords are, however, especially varied and may, above all, reflect the mixed origins of those who carry them. Such weapons include a very broad-bladed, almost trianguler sword (Figs. 4-6 and 17), a more normal sword with a pointed or tapering blade (Figs. 2, 25, 27 and 29), and an essentially non-tapering, distinctly round-ended weapon (Figs. 10, 18 and 28). Other such weapons may be inferred from the shape of their scabbards (Figs. 12, 16, 20, 21 and 23). Of particular interest is a very crude representation of what may be a sword with a curved blade (Fig. 15 and Foto III). 
The mail hauberk is represented by a series of small holes drilled into the stone (Figs. 13, 14, 20 and Foto I). This style of representation is otherwise largely confined to 12 th century Italy. The closest parallel

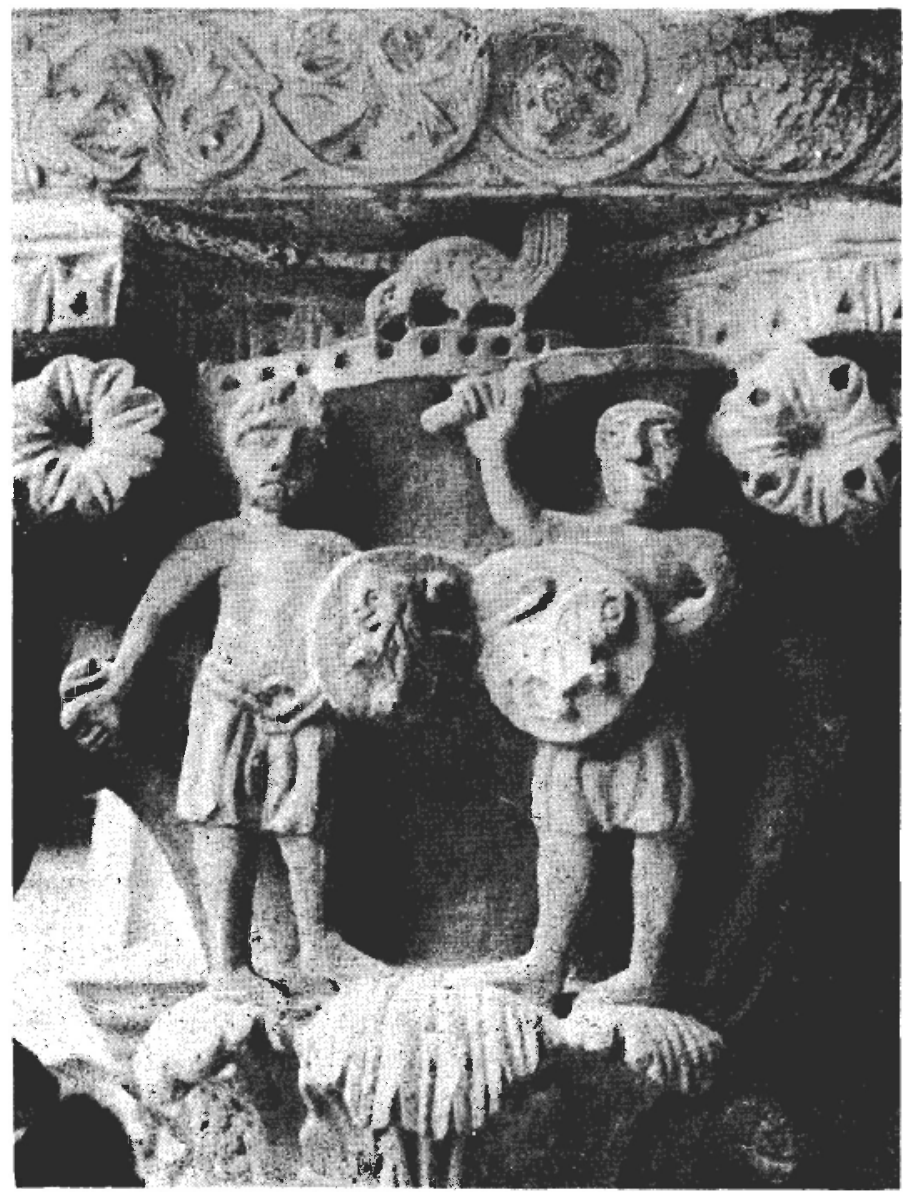

Fото III.-Capital, Cloister of Monreale Catbedral. Lightly protected infantry with bucklers

to these examples at Monreale, both in form of representation and in the style of the short-sleeved hauberk, is to be found on the west front 

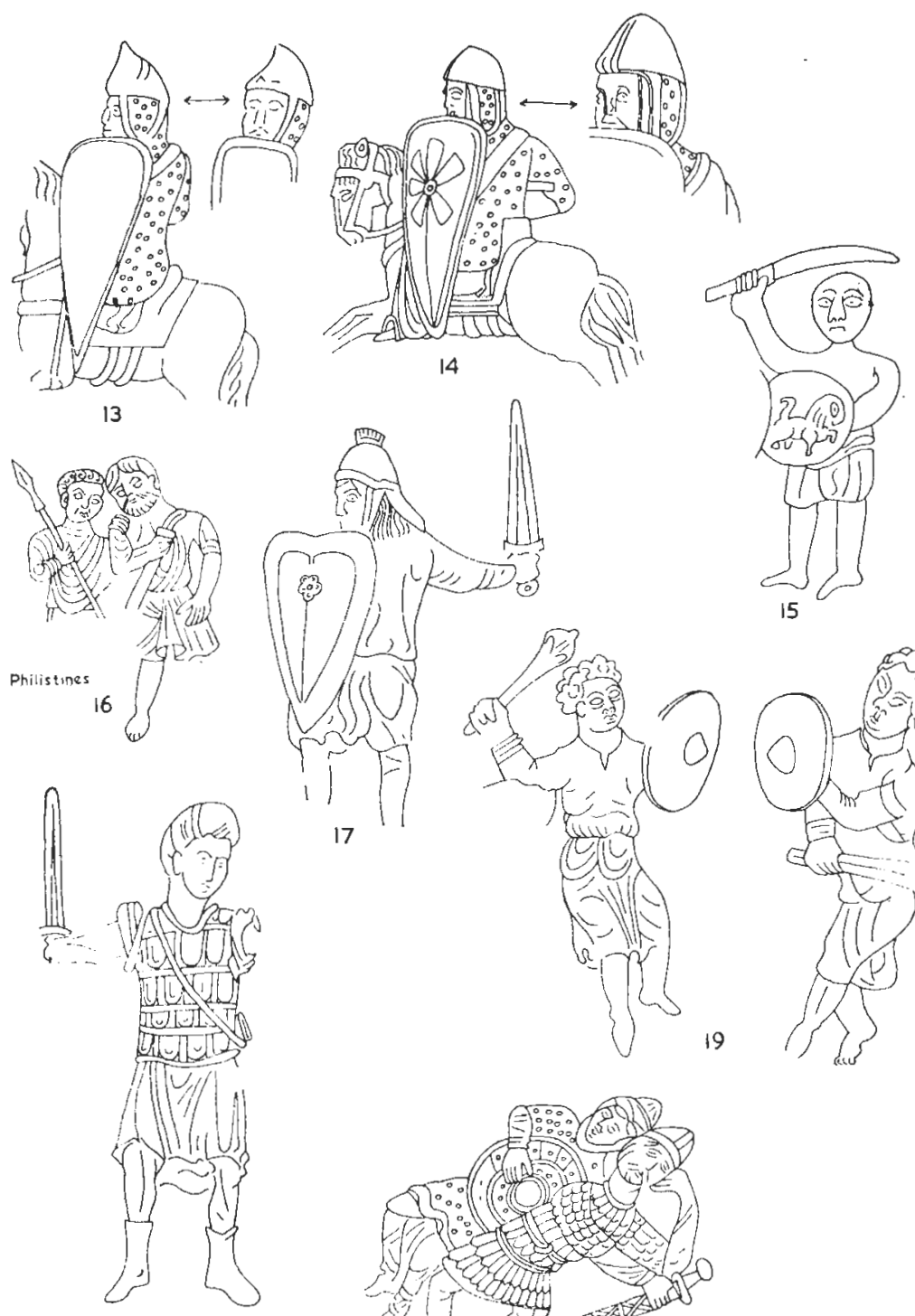

Mossoze of the Innocents

18
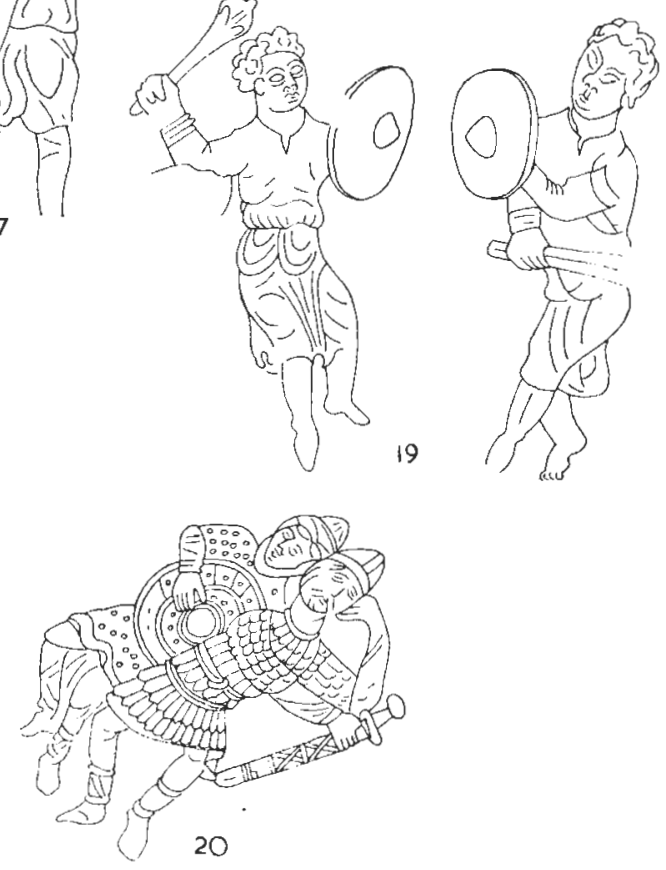

Sleeping Guisrds at the Tomb

FIGs. 13-20.-Capitals in the Cloister of Monreale Catbedral

13-14: «European» style cavalry. 15-20: «Saracen-Byzantine» style infantry 


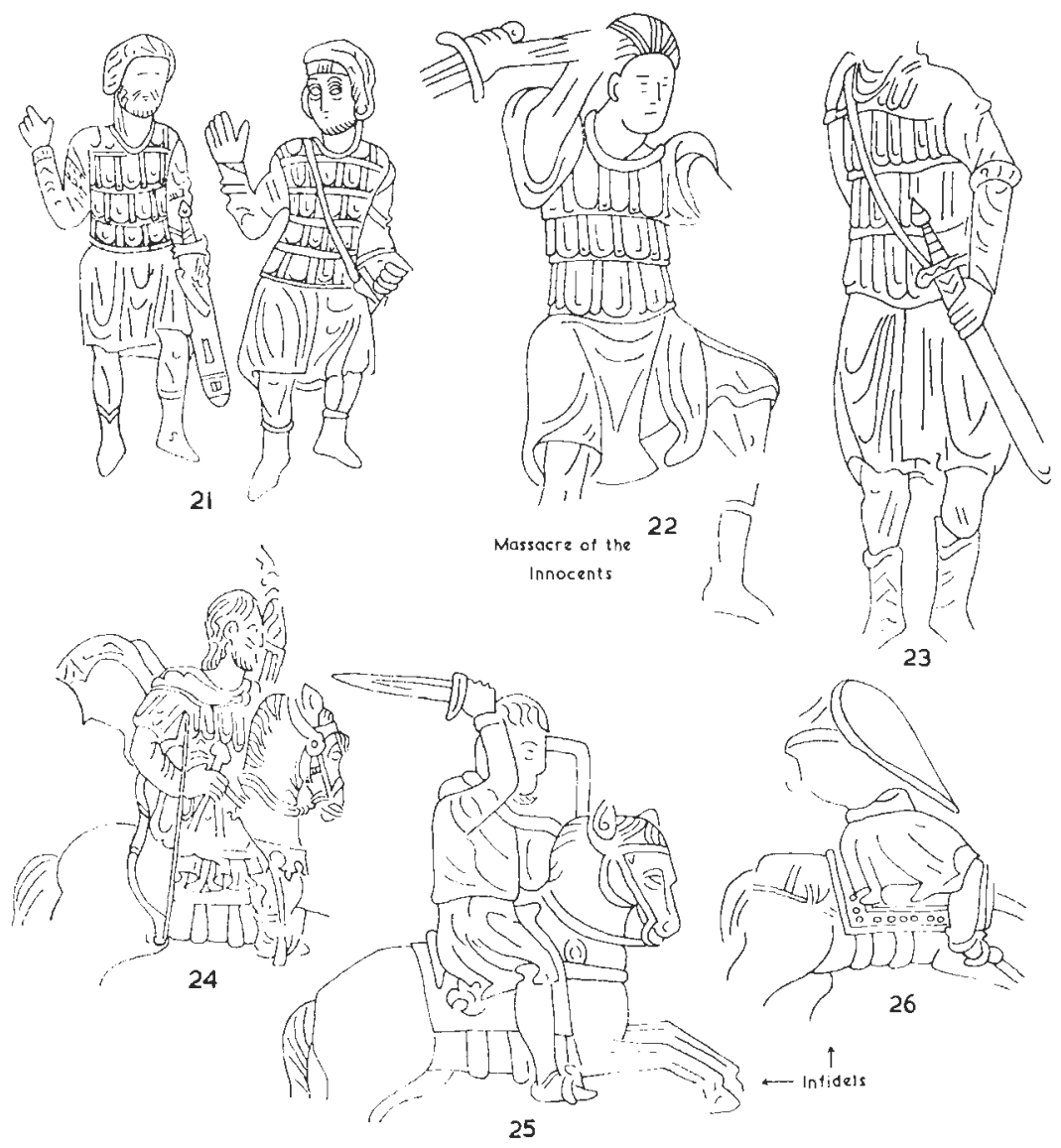

FIGS. 21-26.-Capitals in the Cloister of Monreale Cathedral

21-23: «Saracen-Byzantine» style infantry. 24-26: «Saracen-Byzantine» style cavalry

of the church of San Zeno in Verona (c. 1139 AD). Closer in date to Monreale are some similarly short-sleeved hauberks on the candelabrum made by Nicola d'Angelo and Pietro Vassalletto in the church of St. Peter Fuori la Mura in Rome (c. 1170 AD). Within the Norman kingdom itself short-sleeved mail hauberks, rendered in a somewhat more naturalistic style of closely spaced holes, are shown in early 12 th century carvings over the north door of the church of San Nicola at Bari and on 
a mid-12th century carved lintel over the north door of the church of La Martorana in Palermo (Fig. 49).

Although long-sleeved mail hauberks are found in many Mediterranean lands, on both sides of the religious divide in Spain, in Languedoc, Italy and Egypt, the short-sleeved variety dominated, probably for climatic reasons. Late 12 th century Norman Sicily and southern Italy may, however, have been somewhat of an exception (Figs. 40, 41 and 49). This style had become increasingly rare in the north of Europe as early as the 11 th century. Nevertheless it would be wrong to imagine that the style of armour popularly associated with the «Norman knight», that is, a segmented spangenhelm, a mail hauberk and a large kite-shaped shield, was unknown in southern Italy prior to the Norman takeover. Rather this fashion was one among many to be seen in the pre-Norman Mezzogiorno. Such pre-Norman mail was again short-sleeved and ended above the knees as seen at Monreale (Figs. 20, 47, 49 and Foto I). This more limited mail protection had also often appeared on Byzantine ivories and manuscripts of the 10th and 11 th centuries, either alone or in conjunction with other forms of armour. It may even be seen in a 9th century Psalter (Monastery of the Pantocrator, Mount Athos, Ms. 61, ff. $30 \mathrm{v}$ and $89 \mathrm{r}$ ), and in fact there is little reason to doubt that it had been in continuous fashion since the fall of the Western Roman Empire.

The mailed horsemen of Monreale also show two other interesting features. Their saddles are secured by two girths as are those of other horsemen at Monreale (Figs. 13, 14 and 24-26), yet this was not the case at San Nicola, Bari, nor in any of the 11th century Exultet Rolls of southern Italy. First appearing in southern France in the 11 th century («Atlantic Bible,» Biblioteca Laurenziana, Ms. Edili 126, Florence), this doubled girth had become almost universal throughout western Europe by the late 12 th century. It is, in fact, seen in 12 th century Exultet Rolls and on all the saddles of the Cappella Palatina ceiling in Palermo (c. $1140 \mathrm{AD}$ ). By contrast the helmets worn by these mailed riders at Monreale seem to be specifically Sicilian. They clearly include what can only be described as mailed earflaps (Figs. 13 and 14). There also seem to be no other examples even in Sicily. In Modena Cathedral, beneath the chapel at the east end, there is a 12th century carving of a prone warrior who wears a rare and very early form of sallet helmet that is roughly comparable to many helmets seen in Byzantine and other Middle Eastern illustrations. The lacing that secures this defence beneath the warrior's chin is the nearest one gets in Romanesque Europe to another helmet of the Sicilian ear-flap variety. Perhaps this style was merely a short-lived experiment even in Sicily, and one that happened to coincide with the carving of the Monreale capitals. 
Whereas the mailed warriors of Monreale mostly demonstrate clear western European influence, those warriors wearing scale armour (Figs. 18 and 20-24) seem at first glance to derive from Byzantine pro-
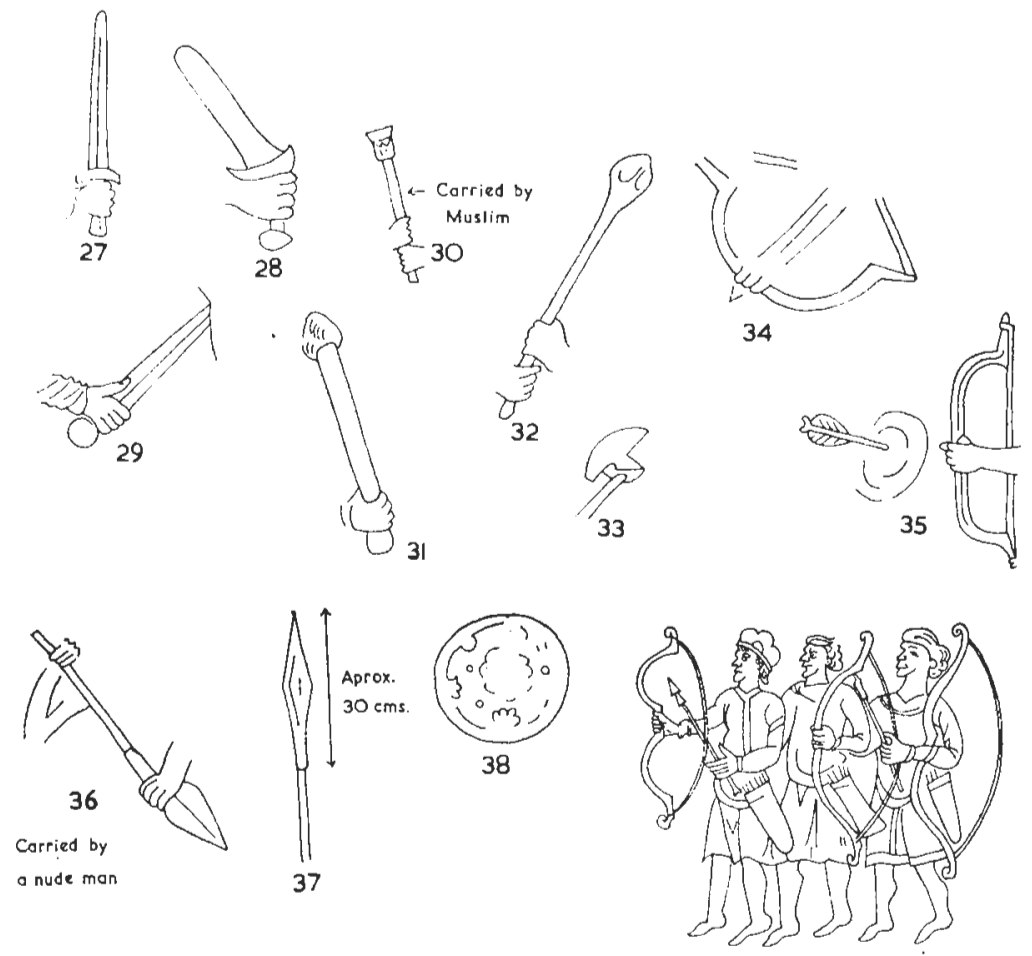

Figs. 27-38.-Capitals in the Cloister of Monreale Cathedral

27-29: Swords, 30-32: Maces. 33: Axe. 34-35: Bows. 36-37: Spears. 38: Shield

totypes, as might other such examples in southern Italy (Figs. 46 and 47). While this may, in fact, be so, it is equally probable that their armours derive more immediately from the Arab world, and thus from Sicily's preceding Muslim era. Such styles of armour, at least in Egypt, Syria and north Africa, might still be traced back to a Byzantine original, either all the way to the pre-Islamic period or to Byzantine influences felt during the early Middle Ages. It is, however, equally possible that an increased use of scale armour in Byzantium from the 8th to 11 th 
centuries was itself a result of both Muslim military pressure and Arab armour fashions. Some such defences at Monreale are worn by warriors who wear 'what looks like a loose turban (Figs. 18, 21, 22 and Foto II). A turban is almost certainly wound around the helmet of a sleeping warrior (Fig. 20) and is seen in other comparable sources (Figs. 39 and 45). The most noticeable feature is, however, the fact that the elements of these armours overlap downwards and are, in most cases, clearly separated by what appear to be leather straps. Hence we have here scale rather than lamellar armour. A short cuirass of this type had for some centuries been popular in Byzantium where it was generally worn with short sleeves of splinted armour. Here its individual scales were also seen overlapping upwards and were, as such, in many ways more akin to laced lamellar than to scale armour. Within the Muslim world a fashion for wearing a sleeveless cuirass that covered the abdomen, chest and shoulders, rather than simply the abdomen and chest as had earlier lamellar cuirasses in Seljuk Iran, grew in popularity in Ayyūbid and Mamlūk times, that is in the later 12th and 13th centuries. This is clearly indicated both in Ayyūbid and Mamlūk metalwork and in Syriac manuscripts from the Jazīra region of northern Mesopotamia. Most such cuirasses consisted of upwards overlapping large lamellae, although downwards overlapping forms were not unknown. A cuirass of this shape, and either of scales or lamellae, is illustrated in an 11th century Exultet Roll from Lombard southern Italy (Museo Civico, Pisa). But most of the cuirasses shown in 11 th century southern Italian manuscripts, 12 th century Sicilian mosaics, and 12th century Sicilian or south Italian carved ivory panels include Byzantine-style splinted sleeves and often a similarly constructed Byzantine-style skirt. The only indisputable south Italian examples of downwards overlapping scales seem, interestingly enough, all to date from the 12 th century. These appear, for example, on an ivory altar-back in the Salerno Cathedral Museum as part of a cuirass that also protects the upper-arms and thighs, on bronze doors designed by Barisanus of Trani at Trani Cathedral (Fig. 46) 'where they are worn by St. George, and, as an exact replica of the Monreale-style of short sleeveless cuirass, being worn by a soldier in a scene of «The Betrayal» in an early 12th century Exultet Roll from Fondi (Bibliothèque Nationale, Ms. Nouv. Acq. 710, Paris).

Some of the helmets worn by otherwise unarmoured figures at Monreale seem to betray equally mixed antecedents. The first type (Fig. 2) is, by the normal standards of 12th century western Europe, very unusual indeed. Since the sculptor has gone out of his way not to indicate joints or hinges where these helmets cover cheek, neck and chin, one may assume that here is a head protection of some flexible material, 

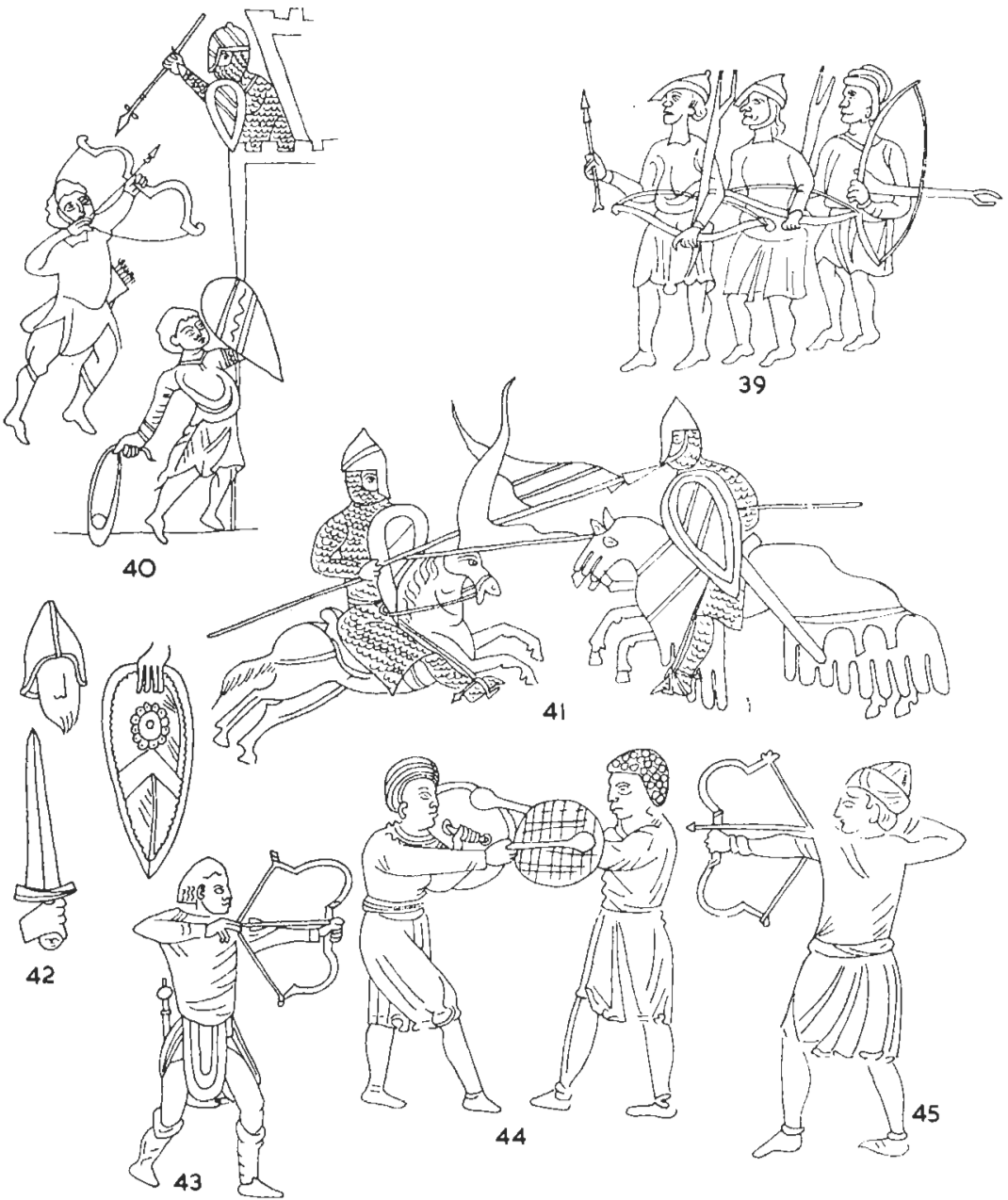

41

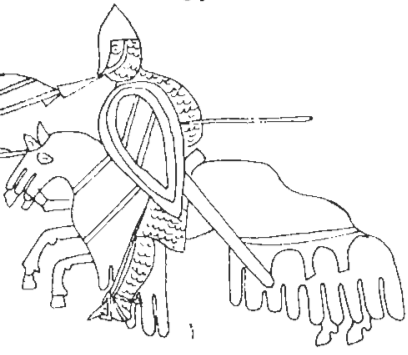

42
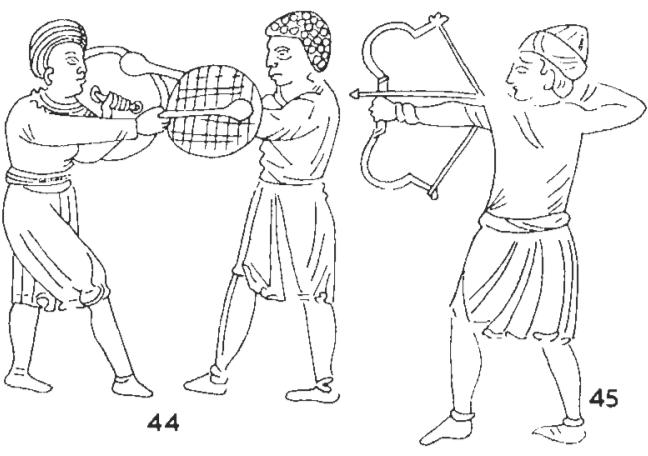

FIGs. 39-45.-Comparative material from Sicily and soutbern Italy

39: «Sicilian archers and crossbowmen,» Chronicle of Peter of Eboli, c. 1197 AD, Sicilian or south Italian (Burgerbibliothek, Ms. Cod. 120/II, Berne). 40: «Constance besieged in Salerno,» Cbronicle of Peter of Eboli, c. 1197 AD, Sicilian or south Italian (Burgerbibliothek, Ms. Cod. 120/II, Berne). 41: «Battle between Sicilian and Imperial Armies,» Cbronicle of Peter of Eb́bli, c. $1197 \mathrm{AD}$, Sicilian or south Italian (Burgerbibliothek, Ms. Cod. 120/II, Berne). 42: «The Emperor's Guard,» Exultet Roll, 12th century Benevento, south Italian (Biblioteca Casanatense, Ms. 724, B i. 13, Rome). 43-45: Bronze door panel, late 12th century, south Italian (Trani Cathedral) 
perhaps leather. Leather, and almost certainly padded, helmets are more frequently mentioned in Arabic and Greek sources than in Latin. Al Tabari describes them, for example, as do various Byzantine military manuals. Helmets of a similar sort, though harder to interpret, appear on many Byzantine manuscripts and in Muslim works of art such as Fătimid carved wood and ivory panels. They are also not uncommon in a south Italian context, although where they do not wrap around beneath a wearer's chin there is no reason to assume that they are not of metal (Fig. 42). Almost identical protections, characterized by the fact that they cover almost the entire head, lack visible joints or hinger, and show a distinct thickness or evidence of padding around the facial opening, are worn by Herod's soldiers on the 12th century ivory altar-back at Salerno and by a presumed 11 th century ivory chess «knight» from southern Italy which is now in Paris (Cabinet des Médailles, Bibliothèque Nationale). More doubtfully they may be worn by the Army of the Emperor on an Exultet Roll from San Vincenzo al Volturno of 981-987 AD (Vatican Library, Ms. Lat. 9820, Rome). A similar form of helmet is certainly worn by both horsemen and infantry on the 11 th century Byzantine ivory casket now in Troyes Cathedral.

A second type of helmet (Fig. 4) has a face-guard astonishingly similar to examples that appear on late Mozarab manuscripts from northern Spain («Beatus,» 1091-1109 AD, British Library, Ms. Add. 11695, London; and the «Avila Bible,» late 12th century, Biblioteca Nacional, Ms. ER 8, f. 324v, Madrid). These are, however, otherwise virtually unknown on either side of the Mediterranean. Another warrior 'wears a probably metal skull-cap that is unusual only for its broad and decorated rim (Fig. 6), while a further, somewhat worn, carving may either illustrate a soft cap or a helmet with some form of flexible neckguard (Fig. 5).

Yet another carving is, however, both clearer and much more unusual (Fig. 17). Its closest parallel is once again in a late Mozarab illumination («Beatus,» c. 1100 AD, Biblioteca Nazionale, Torino), but this latter illustration is far from clear. Helmets with neck-guards, but very rarely with crests and never with such cheek-pieces, are of course common in Byzantine manuscripts of roughly a century earlier ( $«$ Smyrna Octateuque,» late 11 th century, Vatican Library, Cod. Gr. 746, Rome; and «Constantinople Octateuque,» early 12th century, Topkapu Library, Ms. Gr. 8, Istanbul). Dating from a little later than Monreale are some Syriac Gospels from the Jazira area, now in the British Library and the Vatican Library, both of which portray helmets of the same essentially Byzantine form. In Italy this shape, again lacking a crest or cheek-pieces, is clearly represented on the «Rome Casket,» a 12th century carved ivory box from Sicily or southern Italy which is now in the Palazzo Venezia Museum 


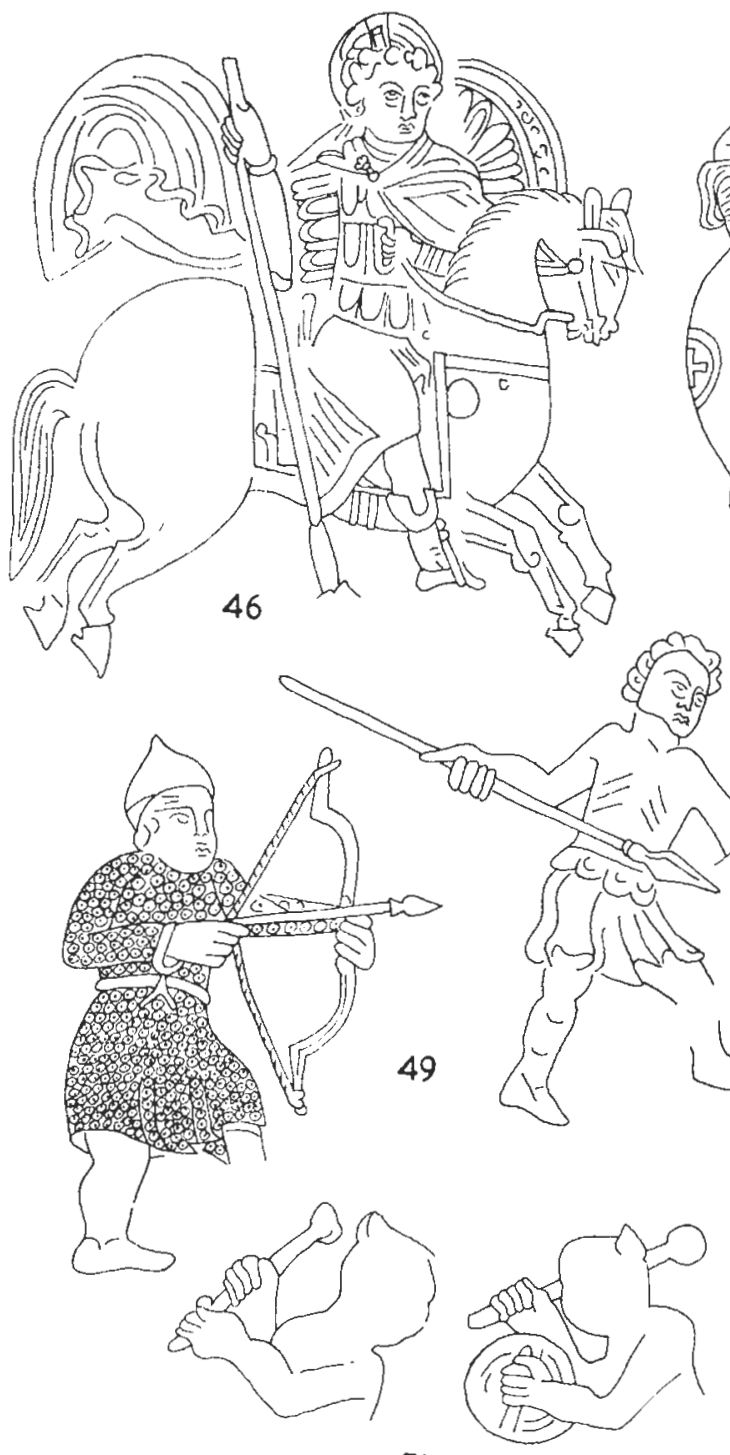

$5 !$
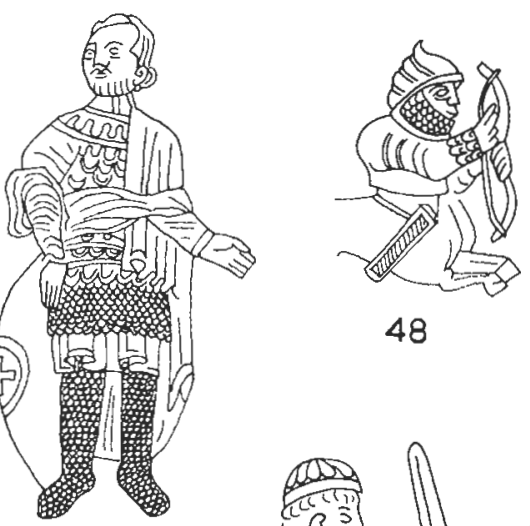

47
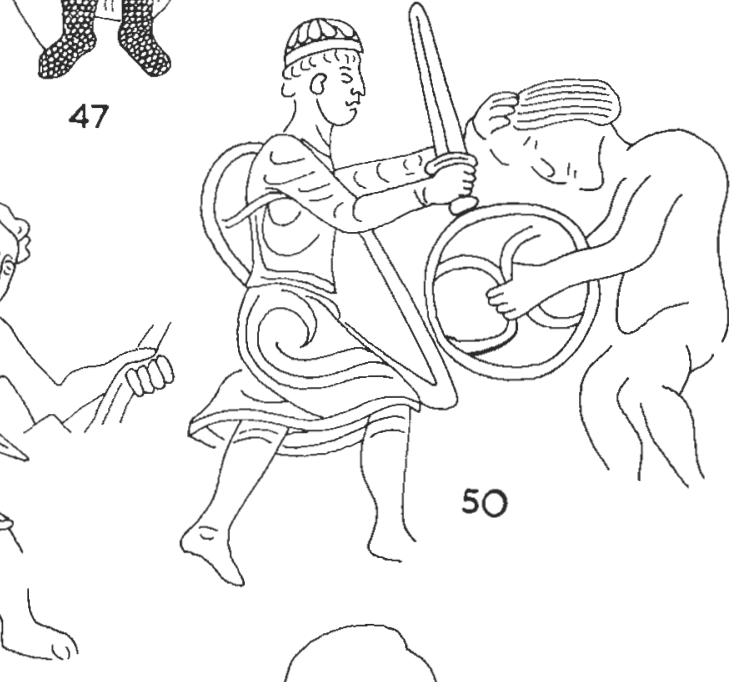

50

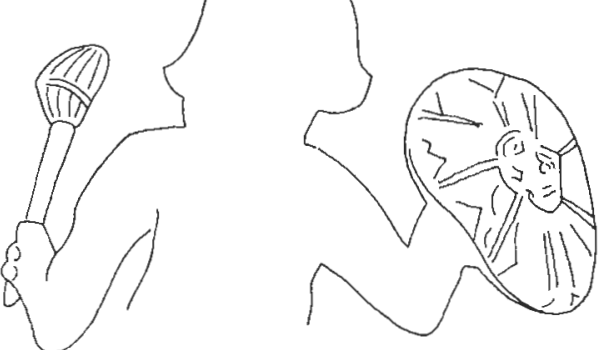

52

FIGs. 46-52.-Comparative material from Sicily and soutbern Italy

46: «St. George,» bronze door panel, late 12th century, south Italian (Trani Cathedral). 47: «St. George,» statue, late 12th century, south Italian (Portal of S. Sofia, Benevento). 48: «Centaur,» relief, c. 1153 AD, south Italian (West front, Cathedral, Bari). 49: «Hunters,» c. 1140 AD, Sicilian (North door, La Martorana, Palermo). 50: Relief, early 12th century, south Italian (West front, San Nicola, Bari). 51: «Demons,» relief, late 12th century, south Italian (Exterior, Cathedral, Barletta).

52: «Merman,» relief, 1175-1200 AD, south Italian (Nave, Cathedral, Bitonto) 
in Rome. The shield carried by the Monreale warrior is also of interest (Fig. 17). It is an almost exact replica of that carried by a demon on a 12th century Frankish capital in Nazareth that portrays a «Believer with the Queen of Faith.» These shields may well be of leather and perhaps had a north African origin. If so, then they are early versions of the famous kidney-shaped Adarga shield that was subsequently carried by almost all «Moors» in late 13 th to 15 th century Spanish art.

The equipment carried by unarmoured figures at Monreale is relatively straightforward. One horseman (Fig. 25) clearly has a tall shield with a flatish top and, since he is in combat with a mailed figure, he probably represents a lightly armed north African, Berber or Arab cavalryman. In other words he is some form of «infidel.» This interpretation is supported by the fact that he is armed only with an almost triangular sword of a type that is carried by those Monreale infantrymen who could well be Sicilian Muslims. Another such «infidel» horseman does, however, carry an ordinary round-topped kite-shaped shield, of a type common in other sources from this region (Figs. 40-42 and 50).

One infantryman, with his tall shield and short broadbladed thrusting or throwing spear (Fig. 11), could have come from almost any country bordering the Mediterranean. In these areas, from the 11 th century onwards, such a tall infantry shield was normally associated with the spear rather than the sword. Examples of armoured or unarmoured such foot soldiers are numerous (Figs. 40 and 49). For instance in the «Liber Testamentorum Regium» of 1126-1129 AD from Oviedo (Oviedo Cathedral Library), on a late 12 th century fresco from the Castilian church of San Baudelio de Berlanga (Museum of Fine Art, Boston), on a 12th century relief of «The Betrayal» in Pistoia Cathedral Crypt, in the late 11 th century carving over the north door of San Nicola at Bari, on a fragment of 11 th century Fattimid lustre ware now in the Victoria and Albert Museum, London, and in the early 12 th century ivory book-covers of «Queen Melisende's Psalter» in the British Museum. At this time and in this area lightly protected sword-armed infantry normally carried a smaller, hand-held rather than arm-supported, shield commonly referred to as a buckler (Figs. 10, 15, 50 and Foto III). Although there are exceptions to this general rule, the evidence in its favour is very strong.

Mention has already been made of both the simple short-bow and the recurve composite bows that appear at Monreale. These seem to have shared the field in the Mediterranean region (Figs. 34, 35, 39, 40, 43, 45, 48 and 49) until the Turkish style of composite bow virtually took over Muslim archery. At this time, of course, the long-bow and crossbow were competing to oust the simple short-bow in north-west Europe. 
Both these weapons may also appear in southern Italy at the very end of the 12th century (Fig. 38).

This leaves the axe and the mace. Around the Mediterranean the former weapon (Figs. 9 and 33) was more common in Spanish and Byzantine sources. An axe very similar to those at Monreale appears, together with a sword, in the hands of a turbaned foot soldier on the Cappella Palatina ceiling of c. $1140 \mathrm{AD}$, but in general the simple axe seems to have been relatively rare as a weapon of war in Sicily.

The same cannot be said of the mace. These are, interestingly enough, more often placed in the hands of heretics, demons, Herod's troops and other such undesirables than into the hands of Christians, by both Byzantine and Italian Romanesque artist. The weapon also appears, though not very frequently, in Fātimid art. In Norman Sicily, meanwhile, it is grasped by apparently negroid warriors at Monreale (Fig. 19) and by a man whose costume probably identifies him as a Muslim (Fig. 30). A mace is also carried by a Centaur on an 11th century ivory oliphant from Salerno (Museum of Fine Art, Boston), by a camel-riding Arab on the Cappella Palatina ceiling, by a number of demons on carved friezes at Barletta Cathedral (Fig. 51), by a two-tailed merman in Bitonto Cathedral (Fig. 52) and by a pair of warriors, one with closely curled and somewhat African hair, on the late 12th century bronze doors of Trani Cathedral (Fig. 44). In all these south Italian examples, 'where shields are carried, they are of the small round hand-held variety. Once again the circumstances in which the mace appears in the Norman kingdom suggest that the mace was primarily an «infidel» weapon.

Now to return to that strange curved sword or knife (Fig. 15). The curved blade had long been known in the east and in the nomadic zones of the Eurasian steppes. Knives that were long enough to be regarded as swords, with long hilts and no quillons just as at Monreale, are shown in the hands of Chaldeans in a 9th century Byzantine "Book of Job» (Vatican Library, Cod. Gr. 749) and in other similarly dated Greek manuscripts. Comparable weapons appear on 9 th and 10 th century Cappadocian frescoes that also betray a strong Islamic costume influence (Kokar Kilise, Peristrema Valley, Hasan Dag) and in 11 th century Byzantine manuscript illustrations of Arabs and Turks. In Egypt a true sword with a slightly curved blade appears on two paper fragments from Fustāt («Two Warriors,» 11th-12th century, Museum of Islamic Art, Cairo; and "Jazrafîl who rides an Elephant,»c. 1200 AD, Department of Oriental Antiquities, British Museum; London). In western Europe at a rather earlier date the curved knife with long hilt and long blade but no quillons, appears in the south French «Beatus of St. Sever,» 1028$1072 \mathrm{AD}$ (Bibliothèque Nationale, Ms. Lat. 8878, f. S, Paris). In Sicily 
a comparable but smaller weapon is used to slay a Muslim child in the «Chronicle of Peter of Eboli,» c. 1197 AD (Burgerbibliothek, Ms. Cod. 120/II, Berne). In Europe these weapons possibly had Byzantine or Muslim antecedents and may themselves have been the forerunners of the heavy, single-edged Falchions that grew in popularity with the warriors of 13 th century Europe.

\section{BIBLIOGRAPHY}

Recent publications on medieval Sicily have been few and of a mixed degree of originality, while earlier studies remain essential reading for all those interested in the Norman Kingdom of southern Italy and Sicily and in its background. The most useful generally available such works are as follows:

Ahmad, A.: A History of Islamic Sicily, Edinburgh, 1975.

AmAri, M.: Biblioteca Arabo-Sicula, Turin-Rome, 1880-1881.

- Storia dei Musulmani di Sicilia, Catania, 1933.

Arata, G. V.: L'Architettura Arabo-Normanna e il Rinascimento in Sicilia, 1925.

Bellafiore, G.: «The Cathedral of Monreale,» Connoisseur, March, 1975.

Bertnux, E.: L'Art dans l'Italie Méridionale, vol. I, Paris, 1904.

Chnlandon, F.: Histoire de la Domination Normande en Italie et en Sicile, Paris, 1907.

Gabriel, F.: «La Politique Arabe des Normands de Sicile,» Siudia Islamica, IX, 1958.

GARTON, T.: «Islamic Elements in Early Romanesque Sculpture in Apulia,» AARP, IV, 1976.

GaY, J.: L'Ttalie Méridionale et l'Empire Byzantin, Paris, 1904.

JAMISON, E.: Admiral Eugenius of Sicily, London, 1957.

- «The Sicilian Monarchy in the Mind of Anglo-Norman Contemporaries,» Proceedings of the British Academv, XXIV, 1938.

Jones, D.: «Romanesque, East or West?», Connoisseur, April, 1976.

NoRwich, J. J.: Kingdom in the Sun 1016-1130, London, 1967.

- The Normans in the South 1130-1194, London, 1970.

Sarre, F.: «L'Arte Musulmana nel sud d'Italia e in Sicilia,» Archivio Storico per la Calabria e la Lucania, Rome, 1933.

ScheTtinI, Fr.: La Scultura Pugliese dall'XI al XII Secolo, Bari, 1946.

VenturI, A.: Storia dell'Arte Italian, vol. III, Milan, 1902.

Wackernagel, N.: Die Plastik des XI und XII Jabrbunderts in Apulien, Leipzig, 1911. 